\title{
BIM FOR REINFORCEMENT DETAILING IN R.C.C FRAME STRUCTURES
}

\author{
Saurabh Kumar ${ }^{1,}$ Jyoti Trivedi ${ }^{2}$ \\ ${ }^{1}$ Student, School of Building Science and Technology, CEPT University, Gujarat, India \\ ${ }^{2}$ Professor, School of Building Science and Technology, CEPT University, Gujarat, India
}

\begin{abstract}
As it rightly said by Ernest Boyer, "The future belongs to the Integrator's", the AEC industry is now adopting BIM, where different information related to a structure is stored in a virtual model before the structure is actually built at the site. In high rise structures (skyscrapers) BIM can play a vital role in reinforcement works as in R.C.C frame structures the cost of structure is mainly governed by reinforcement cost, therefore the level of reinforcement detailing and quantity takeoff is very critical. In this study in order to solve reinforcement related issues we use BIM for reinforcement detailing and quantity takeoff. By using BIM for reinforcement detailing we can minimize the wastage in steel and hence it can bring down the cost. It likewise provides well detailed 3-D drawings which help to visualize (especially in complicated junctions) and can solve many clashes at the site, hence saves time. In this research the results are compared to the case study of BIM vs. Non BIM approach. Bar Bending Schedule created by using BIM is accurate and can easily be changed within clicks when the reinforcement drawing changes (especially in India, where reinforcement drawing often changes to the extent of slab being executed).
\end{abstract}

Keywords: Bar Bending Schedule, Building Information Modeling

$* * *$

\section{INTRODUCTION}

BIM (Building Information Modeling) is a process where the virtual model of a building is prepared digitally. The BIM model contains all the necessary data which are required during construction. When BIM is implemented precisely on a project, it enhances construction process. With development in BIM in AEC industry structural engineers are now finding new ways to solve clashes in projects, provide better detailed drawings rather than estimating quantity and clashes. They also save time in producing these drawings as the changes in the model will update quantities as well and change will reflect in all the views associated with it.

Extensive research has been done in the application of BIM in finding out quantities of concrete, finishing items, brick masonry. This paper deals with the application of BIM in one of the most critical construction activities, i.e., reinforcement works because reinforcement in a R.C.C frame structure acts as a skeleton system of that structure and also the major cost of a R.C.C Structure is governed by reinforcement quantity.

In this research the results are compared to the case study of BIM vs. Non BIM approach. This paper is divided into following parts:

1) To begin with literatures available in the context of BIM and reinforcement detailing are considered.

2) Subsequently two case studies are taken. In the first case study BIM assessment (with BIM and without BIM analysis)is done from the contractor's side and in second one BIM is implemented during execution to verify the result of the Case Study-1

3) The data is collected and analyzed with respect to cost and wastage in reinforcement in RCC structures.

\section{LITERATURE REVIEW:}

The BIM technology existed since 1970s. Building Information Model was first appeared in a 1992 paper by G.A. VanNederveen and F. P. Tolman.In 1987 Grahisoft launches ArchiCAD software which was the first CAD product for the personal computers, which was able to create both $2 \mathrm{D}$ and $3 \mathrm{D}$ geometry. The term BIM was not so popular until Autodesk released a paper titled "Building Information Modeling" in 2002. (9) The US National Building Information Model Standard Project Committee has defined BIM as "Building Information Modeling (BIM) is a digital representation of physical and functional characteristics of a facility. A BIM is a shared knowledge resource for information about a facility forming a reliable basis for decisions during its life-cycle; defined as existing from earliest conception to demolition"(10)

It is not easy to manage a project involving such a large number of people and documents, so some integration concept has to be developed where all information can be stored in a single place therefore AEC industry has found its solution by implementing BIM on various projects.

BIM gains so much importance that International Code Council is preparing SMART codes using BIM for 
automatic checking with codes. The aim of BIM is to reduce the overall effort of structural engineers on a given project for a given fee. Cost of BIM Implementation is not a problem when the project is under budget.61\% of construction firms participated in McGraw Hills Construction Report agree that BIM is important for complex projects. (2)Using Revit (a product of Autodesk) is a faster way to prepare reinforcement detailed drawings with proper cutting lengths of reinforcement bars (4)

It is easy to visualize reinforcement pattern and it helps in reinforcement placement and avoid mistakes during construction and fabrication .BIM could save wastage in reinforcement and can add value for the customers.Bar Bending Schedule created by using BIM is accurate and can easily be changed within clicks when the reinforcement drawings changes BIM increases productivity provides better coordination and visualizations. Structural engineers can focus more on solving problems rather than coordinating and finding clashes and errors. BIM can act as a waste management tool since it finds quantities accurately. (1)

BIM facilitates integrated design and construction process that results in a better quality building at lower cost. A study by (Zhen Liu October 2011) shows that by Implementing BIM can reduce construction waste, waste although its adaptation is relatively slow. (7)

\section{DATA COLLECTION AND ANALYSIS}

The data collected for case study-1 included all the reinforcement drawings and the quantities calculated without using BIM and with BIM. It was found that by using BIM, the contractor was able to find out the left out quantities.

In order to verify the result of the case study-1, the case study-2 was taken which was comparedto small project but was also an R.C.C frame structure of the same nature. All the 2-D reinforcement drawings of the case study-2 were collected and a BIM model was prepared. The quantities and wastage with BIM and without BIM approach were compared.

\subsection{Case Study-1 Introduction}

The project was a high rise residential project. The project comprises of 4 towers $(\mathrm{G}+45)$. The main concern of implementing BIM from the contractor's side is that the project documents were not integrated and engineers got changed so there were many elements whose reinforcement quantity has been left out during calculation. Since the project was a high rise project having typical floors, therefore any quantity variation in the document leads to the huge wastage in the project. So the contractor has implemented BIM and claimed the left out quantities.
Table -1: Case Study-1 Details

\begin{tabular}{|l|l|}
\hline DESCRIPTION & CASE STUDY-1 \\
\hline Type of project & RCC Frame Structure \\
\hline Project location & Mumbai \\
\hline Project cost & INR 388 CR \\
\hline Project details & 4 Towers $(\mathrm{G}+55)$ \\
\hline $\begin{array}{l}\text { Reinforcement Work } \\
\text { Quantity(without BIM) }\end{array}$ & 16388 TON \\
\hline Reinforcement Grade & Fe 500 \\
\hline BIM Implementation & Post Construction \\
\hline
\end{tabular}

Table -2: Case Study-1 Quantity Comparison of BIM andNon BIM Approach (Finding left out quantities).

\begin{tabular}{|c|c|c|c|}
\hline $\begin{array}{l}\text { TOWER } \\
\text { NO. }\end{array}$ & \begin{tabular}{l}
\multicolumn{1}{c}{ A } \\
CLAIMED \\
QUANTITIES( \\
MT)
\end{tabular} & \begin{tabular}{l}
\multicolumn{1}{c}{ B } \\
CLAIMED \\
AS PER \\
BIM \\
MODEL \\
(MT)
\end{tabular} & $\begin{array}{l}\text { C=B-A } \\
\text { DIFF } \\
\text { IN QTY } \\
\text { (MT) }\end{array}$ \\
\hline Tower-3 & 5245.772 & 5250.962 & 5.19 \\
\hline Tower-4 & 3988.394 & 3988.354 & -0.04 \\
\hline Tower-5 & 3836.933 & 3836.433 & -0.5 \\
\hline Tower-6 & 3317.4 & 3334.659 & 17.259 \\
\hline TOTAL & 16388.1 & 16410.69 & 21.909 \\
\hline
\end{tabular}

$\%$ Difference $==(21.909) / 16388.10=0.13 \%$

\section{DIFFRENCE IN QTY (MT)]}

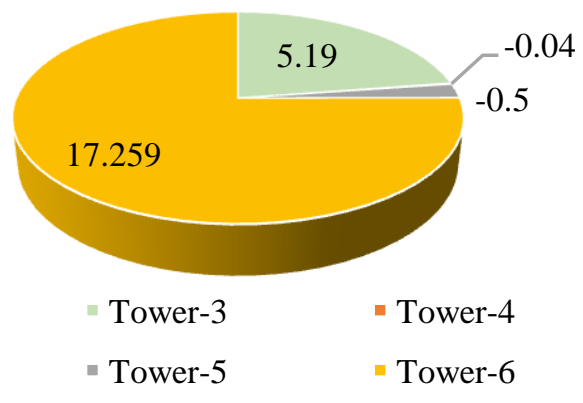

Fig -1: Difference in quantities of BIM and non BIM approach 


\subsection{Case Study-1 Outcomes}

Table -3: Issues at site with Solution through BIM

\begin{tabular}{|l|l|l|}
\hline Sr.No & \multicolumn{1}{|c|}{ Problems } & \multicolumn{1}{c|}{ BIM Solution } \\
\hline 1 & $\begin{array}{l}\text { Drawings and data were not organized properly. } \\
\text { Revised drawings were not kept separate }\end{array}$ & $\begin{array}{l}\text { All the reinforcement drawings and data are integrated in a BIM } \\
\text { Model. }\end{array}$ \\
\hline 2 & Difficult to find left out quantities & $\begin{array}{l}\text { As 3D model was prepared every structural element was } \\
\text { reinforced, so left out quantities can easily be found. }\end{array}$ \\
\hline 3 & $\begin{array}{l}\text { Changes in drawings have been very often, so } \\
\text { quantities should be updated accordingly. }\end{array}$ & $\begin{array}{l}\text { Changes in the drawings will automatically change the quantities } \\
\text { in the model and hence it saves time and money. }\end{array}$ \\
\hline 4 & Manual errors were there in the quantity sheets. & $\begin{array}{l}\text { As the model was visualized in 3-D, chances of manual errors } \\
\text { were eliminated. }\end{array}$ \\
\hline
\end{tabular}

Table -4: Cost Analysis for Case Study-1

\begin{tabular}{|l|l|c|l|}
\hline Sr No. & Description & Quantity Surveyor & BIM Engineer \\
\hline 1 & Salary/month & INR 30, 000/month & INR 35, 000 INR/month \\
\hline 2 & Number of engineers & 3 & 1 \\
\hline 3 & Cost of software & Nil & INR 80,000 \\
\hline 4 & Time taken for Reinforcement steel quantity takeoff (months) & 7 & 5 \\
\hline 5 & Total cost & INR 6,30,000 & INR2,55,000 \\
\hline 7 & Cost Saved by BIM & - & $\begin{array}{c}\text { INR 9,85,905 } \\
\text { (Refer Note) }\end{array}$ \\
\hline
\end{tabular}

NOTE: 1. Costsaved by BIM, is calculated by quantity recovered multiplied by my market rate of steel (INR 45, $000 * 21.909)$.

2. Total cost $=($ salary/month $*$ number of engineers $*$ time $)$ +software cost.

2. Cost of BIM software is INR 2, 00,000 in total but cost considered IS INR 80, 000 because software is used to calculate the quantityof concrete and formwork as well.

3. Salary of engineer which is taken into account is only for the Bar Bending Schedule preparation work.

\subsection{Case Study-2 Introduction}

The project was a 5 floor residential project. The project in comparison to the previous case study- 1 is smaller. The BIM is implemented parallel to the traditional way of Non BIM approach. The quantity take off for all the construction materials is done by the same engineer at site. There were many complicated junctions in reinforcement which has been solved by BIM (in case of combined footing).The decision of implementing BIM is taken by the owner of the project because of his previous losses in wastage and to get the nearest estimated quantity of steel used in the project. The BIM and non BIM based quantities were compared at different phases of construction so that the client can monitor the wastage at various levels. Although the project was small scale but BIM has delivered its benefits. Since the BIM is implemented from the clients' side so BIM is implemented right from the beginning of the project,so at various stages the reinforcement quantities with BIM and without BIM based were compared. Hence by monitoring through BIM they easily found out the wastage at different construction levels.

Table -5: Case Study-2 Details

\begin{tabular}{|l|l|}
\hline Description & Case Study -2 \\
\hline Type of project & R.C.C Frame Structure \\
\hline Project location & Ahmedabad \\
\hline Project cost & INR 8 CR \\
\hline Project details & $\begin{array}{l}\text { 1 Tower (Parking +5 Typical } \\
\text { Floors) }\end{array}$ \\
\hline $\begin{array}{l}\text { Reinforcement Work } \\
\text { Quantity }\end{array}$ & 34.816 TON \\
\hline $\begin{array}{l}\text { Reinforcement Grade } \\
\text { BIM Implementation }\end{array}$ & Fe 500 \\
\hline $\begin{array}{l}\text { Level of detail of } \\
\text { drawings }\end{array}$ & All 2D And 3D drawings \\
\hline
\end{tabular}

\subsection{Case Study-2 Methodology}

In Case study-2 the entire model of the structure in virtually modeled and the quantities of reinforcement is exported and compared with the quantities with the Non BIM approach. The difference in quantities is analyzed and the wastage has been calculated as given in table-6. Fig 2 gives the methodology adopted. 


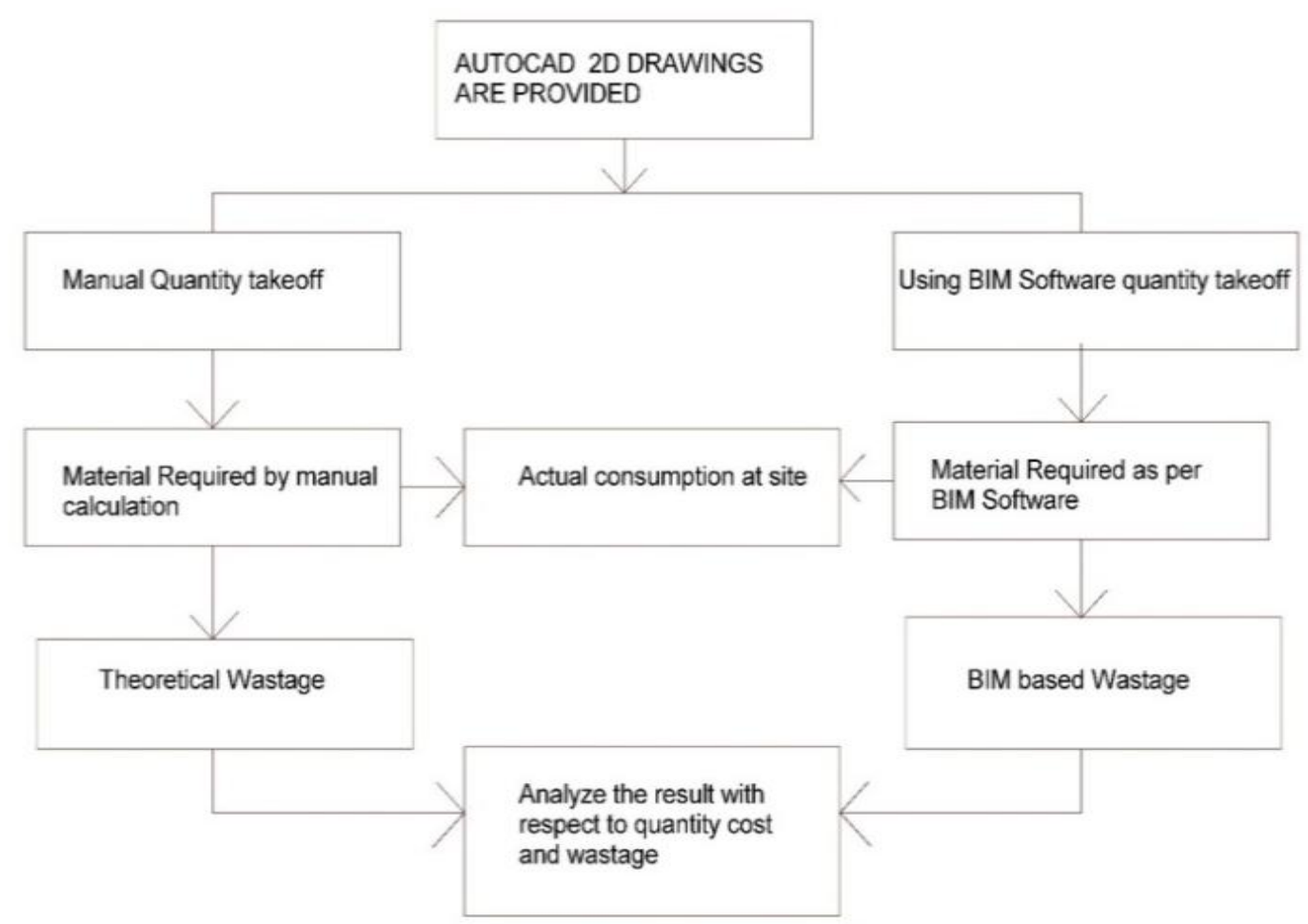

Fig -2: Methodology Adopted for Case Study-2

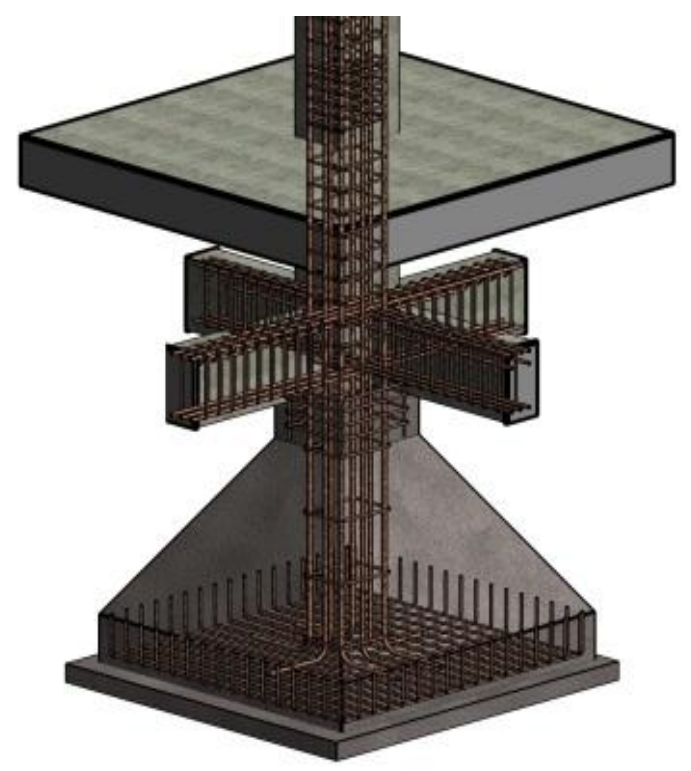

Fig -3:Footing reinforced by using BIM.

Table -6: Quantity Comparison BIM and Non BIM approach for Case Study-2

\begin{tabular}{|l|l|c|c|c|}
\hline Sr.no. & Description & $\begin{array}{c}\text { A } \\
\text { BIM Based Quantity (MT) }\end{array}$ & $\begin{array}{c}\text { B } \\
\text { Without BIM Based Quantity(MT) }\end{array}$ & $\begin{array}{c}\text { DIFF } \\
\text { (MT) }\end{array}$ \\
\hline 1 & Total Quantity in Column verticals & 12.752 & 13.201 & 0.449 \\
\hline 2 & Total Quantity in column footings & 1.121 & 1.124 & 0.003 \\
\hline 3 & Tie beams & 1.198 & 1.187 & -0.011 \\
\hline 4 & Typical floor beams & 12.690 & 13.21 & 0.52 \\
\hline 5 & Typical floor (slabs+stairs) & 7.055 & 8.021 & 0.966 \\
\hline & Total & 34.816 & 36.743 & 1.927 \\
\hline
\end{tabular}


Table -7: Wastage Comparison BIM vs. Non BIM Approach

\begin{tabular}{|l|l|l|}
\hline $\begin{array}{l}\text { ACTUAL } \\
\text { CONSUMPTIO } \\
\text { N AT SITE } \\
\text { (METRIC } \\
\text { TON) }\end{array}$ & $\begin{array}{l}\text { MATERIAL } \\
\text { WASTAGE } \\
\text { AS PERBIM } \\
\text { BASED } \\
\text { PROCESS } \\
\text { (TON) }\end{array}$ & $\begin{array}{l}\text { MATERIAL } \\
\text { WASTAGE AS } \\
\text { PER NON BIM } \\
\text { PROCESS } \\
\text { (TON) }\end{array}$ \\
\hline 13.345 & 0.593 & 0.114 \\
\hline 1.237 & 0.116 & 0.113 \\
\hline 1.265 & 0.067 & 0.078 \\
\hline 13.82 & 1.130 & 0.61 \\
\hline 8.325 & 1.270 & 0.304 \\
\hline 37.992 & 3.176 & 1.249 \\
\hline
\end{tabular}

Note: Material wastage $=($ actual consumption - actual BIM and non BIM based quantities).

$\%$ Difference $=\mathbf{=}(\mathbf{3 6 . 7 4 3 - 3 4 . 8 1 6}) / 34.816=\mathbf{5 . 5 3} \%$

(Non BIM Approach quantity - BIM based approach quantity) / Non BIM Approach quantity* 100

\section{QTY(ton) CALCULATED AS PER BIM APPROACH}

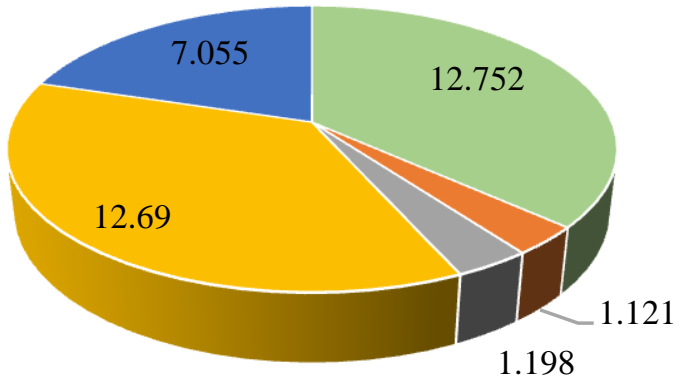

- TOTAL QTY IN COLUMN VERTICALS

- TOTAL QTY IN COLUMN FOOTINGS

- TIE BEAMS

- TYPICAL FLOOR BEAMS

- TYPICAL FLOOR SLABS

Fig -4: Quantities as per Non BIM Approach

\section{QTY (ton) CALCULATED AS PER NON BIM APPROACH}

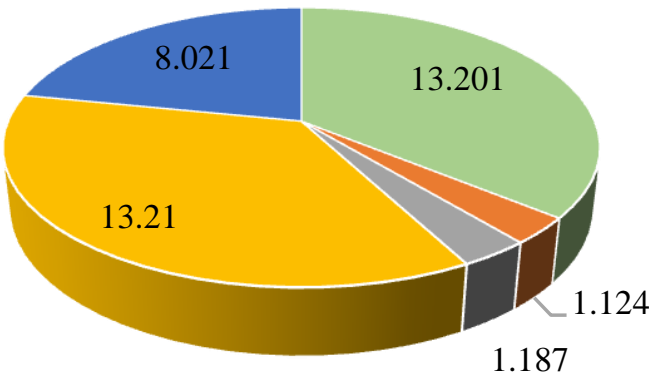

- TOTAL QTY IN COLUMN VERTICALS

- TOTAL QTY IN COLUMN FOOTINGS

- TIE BEAMS

- TYPICAL FLOOR BEAMS

- TYPICAL FLOOR SLABS

Fig -5: Quantities as per BIM Approach

Table -8: Cost Study of Case Study-2

\begin{tabular}{|c|c|c|c|}
\hline $\begin{array}{l}\text { Sr } \\
\text { No. }\end{array}$ & Description & $\begin{array}{l}\text { Quantity } \\
\text { Surveyor }\end{array}$ & $\begin{array}{l}\text { BIM } \\
\text { Engineer }\end{array}$ \\
\hline 1 & $\begin{array}{l}\text { Salary/month } \\
\text { (excluding site } \\
\text { reinforcement } \\
\text { checking work) }\end{array}$ & $\begin{array}{c}\text { INR } \\
28,000 / \text { month }\end{array}$ & $\begin{array}{c}\text { INR } \\
31,000 / \text { month }\end{array}$ \\
\hline 2 & $\begin{array}{l}\text { Number of } \\
\text { engineers }\end{array}$ & 2 & 1 \\
\hline 3 & Cost of software & Nil & INR 80,000 \\
\hline 4 & $\begin{array}{l}\text { Time taken for } \\
\text { Reinforcement } \\
\text { steel quantity } \\
\text { takeoff (months) }\end{array}$ & 3 & 2 \\
\hline 5 & $\begin{array}{l}\text { Total cost for } \\
\text { 8months }\end{array}$ & INR $1,68,000$ & INR $1,42,000$ \\
\hline 6 & $\begin{array}{l}\text { The amount } \\
\text { recovered through } \\
\text { BIM }\end{array}$ & 0 & $\begin{array}{l}\text { INR 86,715 } \\
\text { (Refer Note) }\end{array}$ \\
\hline
\end{tabular}

Note: 1.Thecost saved by BIM, is calculated by quantity recovered multiply by market rate of steel (INR 45,000* 1.927)

2. Total cost $=($ salary/month $*$ number of engineers $*$ time $)$ +software cost. 


\section{Cost of BIM software is INR 2, 00, 00 in total but cost}

considered here is INR 80,000 because software is used to calculate the quantity of concrete and formwork.

4. Salary of engineer which is taken into account is only for the Bar Bending Schedule preparation work.

\subsection{Reliability of BIM based Software}

It is clear that using BIM software cut down the cost and manual work in quantity take off of reinforcement works. As explained by AEC magazine (2013) cost estimates are more precise due to parameters attached to the elements and the ability to label model content and categorized them into different items.

During the research the BIM Engineer explained how the BIM software can reduce the human errors by referring different views during modeling of elements. There are many plugins compatible with BIM software such as Sofisitk which increases the potential of software and give more accurate results and enhance speed of modeling of structures

\subsection{Reliability of BIM Based Bar Bending Schedule}

In the model the hook lengths, concrete cover, etc. all parameters are there in the BIM software which must be considered during placement of reinforcement bars in the model. The BIM model also contains various templates which can be modified according to Client's requirements and if any bar is left to be tagged in the model, then on the schedule its mark will be shown blank and we can easily find and tag it. Hence it can decrease the risk of incorrect manual inputs in the projects.

\section{CONCLUSION}

From this research study, it is clear that adopting BIM in projects will lead to reduction in wastage as well as it is cost effective, if it is implemented at the start of the project till the completion of the project. BIM initially may add cost to the project but with time it has the ability to give positive returns since the manual calculation will lead to errors. In Case Study-1 BIM has been implemented just to find out the left out quantities since it was implemented from the contractor side but if it was implemented right from the beginning of the project, the exact wastage could have been found out (as done in Case Study-2). So BIM is much more useful from the client perspective as it can monitor the wastage done by the contractor because he/she then knows the actual quantities with justification in BIM model. BIM can be beneficial to contractors for clash detection, during execution and finding out the maximum quantities he/she can claim. So BIM is beneficial both for the contractors and clients because they both want to know the actual figure of quantity of materials to be ordered at the site with justification.
Benefits of BIM as far as reinforcement works are considered are summarized below:

1. BIM will lead to cost saving in RCC frame structures and the amount saved (wastage) is directly proportional to the scale of the project. It's very effective in terms of cost saving when the structure is a high rise (skyscraper) as numberof floors increases reinforcement quantity.

2. BIM hence reduced waste generated on site as it export proper Bar Bending Schedule from its models leading to reducing of bar cutting wastage onsite. It provides well detailed 3D drawings which help to visualize (especially in complicated junctions) and can solve many clashes at the site, hence saves time. Leading BIM software's are able to export information of models in excel and dwg format which is widely used in every large and small scale projects.

3. BIM easily identifies the left out (missing) quantities because of its strength in producing $3 \mathrm{D}$ visuals which solves many critical junctions easily.

Table -9: Bar Bending Schedule preparation cost

\begin{tabular}{|c|c|c|}
\hline Description & $\begin{array}{l}\text { Non BIM } \\
\text { Approach }\end{array}$ & $\begin{array}{l}\text { BIM } \\
\text { Approach }\end{array}$ \\
\hline $\begin{array}{l}\text { Bar Bending } \\
\text { Schedulepreparation } \\
\text { cost for case study-1 }\end{array}$ & INR $63,0,000$ & INR 2,55,000 \\
\hline $\begin{array}{l}\text { Bar Bending } \\
\text { Schedulepreparation } \\
\text { cost for case study-2 }\end{array}$ & INR $1,68,000$ & INR $1,42,000$ \\
\hline
\end{tabular}

Note: Refer table 3 and table 8 for details

Table -10: Results of the two Case Studies

\begin{tabular}{|l|c|}
\hline Description & $\%$ \\
\hline $\begin{array}{l}\text { \% of reinforcement left out quantities } \\
\text { recovered during reconciliation in }\end{array}$ & $0.13 \%$ (Refer \\
$\begin{array}{l}\text { Case Study-1 (Implemented from } \\
\text { contractor's side) }\end{array}$ & Table-2) \\
\hline $\begin{array}{l}\text { Wastage reduction in Case Study-2 1 } \\
\text { (Implemented from client's side) }\end{array}$ & $\begin{array}{c}5.53 \% \text { Refer } \\
\text { Table-6) }\end{array}$ \\
\hline
\end{tabular}

For implementing BIM in reinforcement work at a site, a well experienced person which is familiar with construction site activities and also with BIM tools are required which is rare combination in India.

The initial cost of BIM is high, so most owners and contractors refuses to adopt BIM. Reinforcement in BIM requires high technical skills. It takes time in modeling, structural elements. However, when often changes in drawings take place it modifies quantity within few clicks.

\section{ACKNOWLEGEMENT}

First and foremost, I would like to acknowledge the institute- Faculty of Technology for providing me with the opportunity to explore the subject of "BIM FOR REINFORCEMENT DETAILING IN RCC FRAME STRUCTURES" 
I would take this opportunity to express deep gratitude to my guide, Prof. JyotiTrivedi, for her continuous guidance and support right from the beginning of this study to its completion. I am extremely grateful to Mr. Hiren Patel for his support so that I can learn BIM related software in his BIM studio. Last but not the least I would like to thank my family members for external support and patience. I would also like to thank God to provide me the strength to complete the thesis work.

\section{REFERENCES}

[1]. Arpit A. Bhusar, Ashish R. Akhare, Application of BIM in Structural Engineering, October 2015, SSRG International Journal of Civil Engineering.

[2]. William F Ikerd, Importance of BIM in Structural Engineering, Oct 2008, Structural Magazine.

[3]. Cesar Augusto Hunt, Benefits of using BIM in Structural Engineering, Jan 2013, Thesis, Utah State University, Utha, U.S

[4]. Craig Larkin, Faster path to accurate reinforcement, Sofisitk Manual (BIM software Plugin)

[5]. Celsa Steel Service, (Largest Steel Manufacturer in U.K.), BIM for Efficient Reinforcement Production

[6]. Chuck Eastman, Paul Teicholz, BIM Handbook

[7]. Zhen Liu, The potential use of BIM to aid construction waste minimization, October 2011,Loughborough University Institutional Repository

[8]. IS Codes- IS 456, SP34, SP 16

[9]. BIM as per Wikipedia,

https://en.wikipedia.org/wiki/Building_information_modelin g

[10]. US National BIM Standard

https://www.nationalbimstandard.org/

[11].Autodesk,

http://www.autodesk.com/solutions/bim/overview

[12].Building Construction Authority (Singapore), https://www.bca.gov.sg/bim/bimlinks.html

[13].Salman Azhar, Michael Hein and Blake Sketo ,Building Information Modeling (BIM): Benefits, Risks and Challenges, McWhorter School of Building Science Auburn University

[14].BIM - Jason A Smith, MRICS, FInstCES, A Contractors Perspective1, Institute of Civil Engineering Surveyors, UK

[15].Smart Market Report,McGraw Hills Construcion 2014

[16]. Robert Eadie1, Henry Odeyinka2, Mike Browne2, Clare McKeown2 and Michael Yohanis2, Building Information Modelling Adoption: An Analysis of the Barriers to Implementation, Journal of Engineering and Architecture March 2014

[15]. J. Vinoth Kumar* and Mahua Mukherjee, Department of Architecture and Planning, Indian Institute of Technology, Scope of Building Information Modeling (BIM) in India, Journal of Engineering Science and Technology, December 2009

[16]. Manish Mandhar1 ,Meenakshi Mandhar2, BIMING THE ARCHITECTURAL CURRICULA - INTEGRATING BUILDING INFORMATION MODELLING (BIM) IN ARCHITECTURAL EDUCATION, INTERNATIONAL
JOURNAL OF ARCHITECTURE (IJA) Volume-1 January - December (2013)

[17]. ShrikantBhuskade, Building Information Modeling (BIM), May 2015,International Research Journal of Engineering and Technology (IRJET) e-ISSN: 2395 -0056 Volume: 02

[18]. DooyongAhn, Heesung Cha, Integration of Building Maintenance Data in Application of Building Information Modeling (BIM), June 2014, ournal of Building Construction and Planning Research

[19]. EmadElbeltagi1 ,Ossama Hosny2 , Mahmoud Dawood1 and Ahmed Elhakeem3, BIM-Based Cost Estimation/ Monitoring For Building Construction,July 2014, Journal of Engineering Research and Applications [20]. Z. Zahrizan1 ,Nasly Mohamed Ali2 , Ahmad Tarmizi Haron3 , Amanda Marshall-Ponting4, ZuhairiAbd Hamid5, EXPLORING THE ADOPTION OF BUILDING INFORMATION MODELLING (BIM) IN THE MALAYSIAN CONSTRUCTION INDUSTRY: A QUALITATIVE APPROACH, Aug 2013,Volume 02 IJRET: International Journal of Research in Engineering and Technology

\section{BIOGRAPHIES}

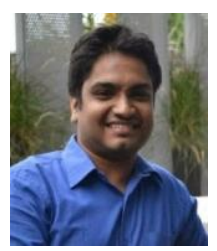

Saurabh Kumar

Student:School of Building Science and technology, CEPT University,

Ahmedabad,Gujarat

Exp: 2years working as a trainee in various BIM project

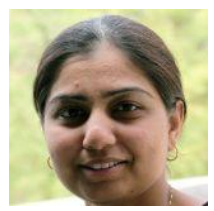

\section{Prof. Jyoti Trivedi}

Faculty: School of Building Science and technology ,CEPT University, Ahmedabad, Gujarat, Exp: 10 yrs in teaching and 3 yrs in Industry 